\title{
Virtual Reality Technology in Physics Learning: Possibility, Trend, and Tools
}

\author{
Agus Setyo Budi ${ }^{1, a)}$, Dadan Sumardani ${ }^{2, b)}$, Dewi Muliyati ${ }^{1}$, Fauzi Bakri ${ }^{1}$, \\ Po-Sheng Chiu ${ }^{2, c)}$, Mutoharoh ${ }^{3}$, Marlinda Siahaan ${ }^{4}$ \\ ${ }^{1}$ Physics Education Department, Universitas Negeri Jakarta, Jakarta Timur, 13220, Indonesia \\ ${ }^{2}$ Teachers College, National Chiayi University, Taiwan \\ ${ }^{3}$ Industry Engineering, Universitas Krisnadwipayana, Bekasi, Jatiwaringin, 13077, Indonesia \\ ${ }^{4}$ Faculty of IT, Universitas Advent Indonesia, Bandung Barat, 40559, Indonesia
}

凹: a)agussb@unj.ac.id, b)s1090815@mail.ncyu.edu.tw, ${ }^{\text {c) }}$ chiups@mail.ncyu.edu.tw

\begin{abstract}
This study aims to disclose how virtual reality technology has been applied to studies of learning and the possibility of virtual reality by reviewing studies that have employed the virtual reality approach. A total of 15 papers were selected from the Scopus Index database from 2015 to 2020. Content analysis showed that virtual reality and physics learning had received the most attention under the theme of student perception, especially in self-efficacy and experience, followed by satisfaction, motivation, and engagement. Trends of research development show that the use of virtual reality has proliferated recently. Moreover, HTC Vive is the most powerful device to conduct the VR study for the tool device. This study concludes that virtual reality technology provides a promising media for educational researchers.
\end{abstract}

Keywords: instructional design, immersive technology, systematic literature review

\section{INTRODUCTION}

Virtual reality with its powerful in visualizing abstract concepts has become an interesting subject to discuss in physics learning. Virtual Reality (VR) can be the perfect catalyst for delivering complex physics concepts through exciting education. VR has powerful potential to enables students to have an immersive learning experience to enhance their learning effectiveness and motivation (Chang et al. 2020). The emergence of new digital tools supporting immersive and engaging learning through VR opens up new paths for both distance and classroom learning (Pirker et al. 2018).

Learning in the classroom using VR in physics has been done simultaneously. On a broad spectrum, VR can help teachers limit their practice in the school. Technology VR has become an important topic of education in recent years (Chang et al. 2020) and has the potential to overcome natural constraints and present things that would not be visible in the physical world (Greenwald et al. 2018). This potential can be a great deal for teachers to make the VR a powerful tool for physics learning and allows students to become highly immersed in complex physics topics. Although the character of students during physics learning is also still considered. Characters that usually appear during the physics learning process include responsibility, creativity, honesty, perseverance, discipline, and tolerance (Anita and Novianty 2020).

This research will focus on how VR becomes a catalyst for physics learning. We will focus on three essential aspects: the possibility of how VR can help educators, trends from VR, and tools used to conduct VR-based learning. 
In this study, we review empirical studies that have employed virtual reality technology to probe the learning processes in the physics classroom. By analyzing relevant works of the past five years (since 2015), we expect to disclose how the virtual reality approach has been applied to the studies of different learning topics and the kind of virtual reality used in physics classrooms.

\section{METHODS}

\section{Paper Selection}

The method of this article is the Systematic Literature Review (Hamilton et al. 2021). The literature source for this review was the Scopus Index database, one of the highly recognized databases indexing journals in the social sciences. The document type was limited to journal articles to review studies of potentially more consistent quality. Systematic reviews can benefit by synthesizing prior work, better informing practice, and identifying critical new directions for research (Borrego et al. 2014).

For data mining, we use the Scopus Application Programming Interface (API) to get the title, author, and abstract, using Publish or Perish by Harzing (Harzing 2007).

The procedures to identify the research papers of this study can be classified into four stages (FIGURE 1). In the first stage, four sets of keywords were organized for searches using the Boolean operator 'AND,' including "virtual reality* AND physics", "virtual reality AND science", "virtual reality* AND learning", as well as "virtual reality AND education." When the results were produced, we classified the subject areas to physics.

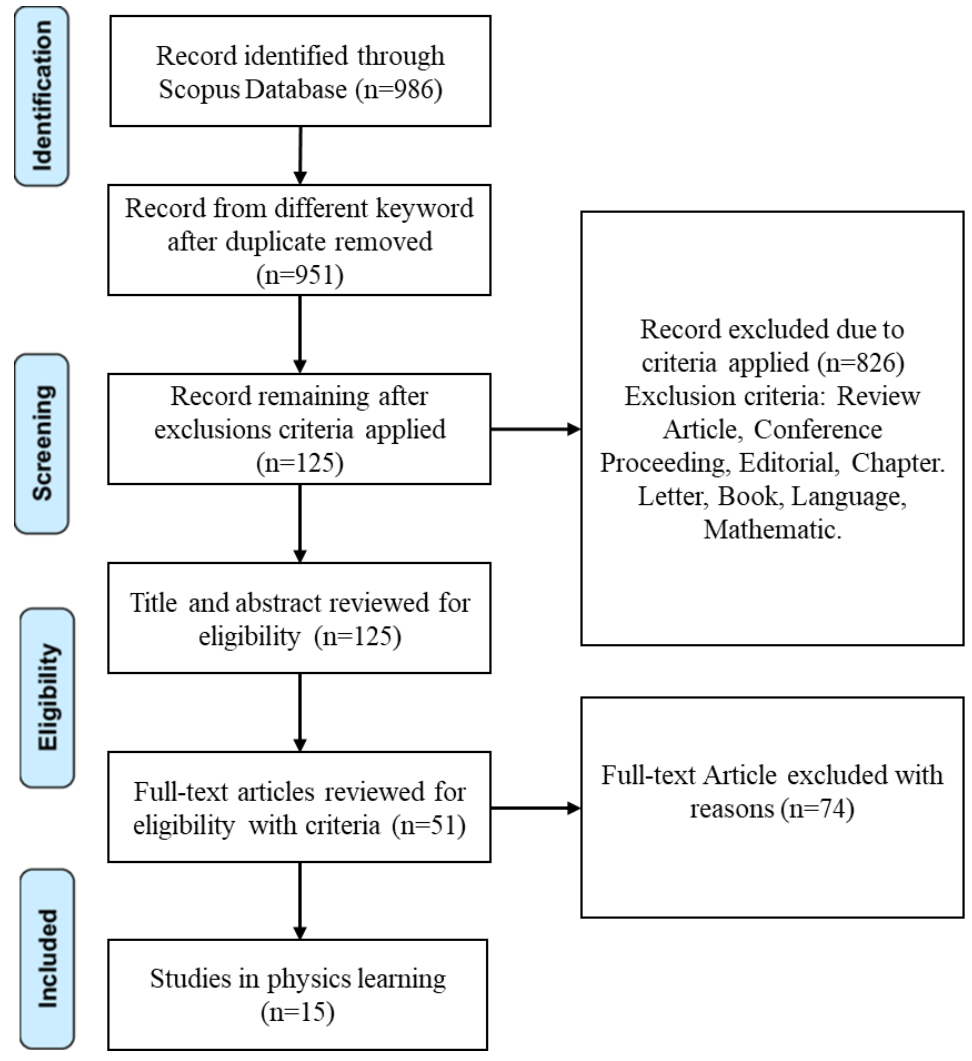

FIGURE 1. The Step of Systematic Literature Review.

In the next stage, we manually and systematically screened the article titles and abstracts. We confirmed that the selected articles do not include system development without educational experiments because the focus of this article is to see virtual reality for teaching physics concepts.

Finally, 15 papers were identified as the research sample of this review. The content analysis was preliminarily coded based on its learning topics to specify different aspects of virtual reality. 


\section{Coding}

The content analysis consisted of three stages. In the first stage, the content of a selected paper was preliminarily coded based on its performance measurement to specify different aspects examined during virtual reality research. We code on the specified article using Atlas. Ti 9 to make it easier to analyze qualitative data between articles.

In the second stage, all papers of different learning frameworks then coded for the research questions or purpose. In the last step, through cross-examination of the research questions/purpose and the virtual reality indications identified in each paper, several thematic linkages were generated, which describe how the virtual reality studies were connected to the issues of learning (FIGURE 2).

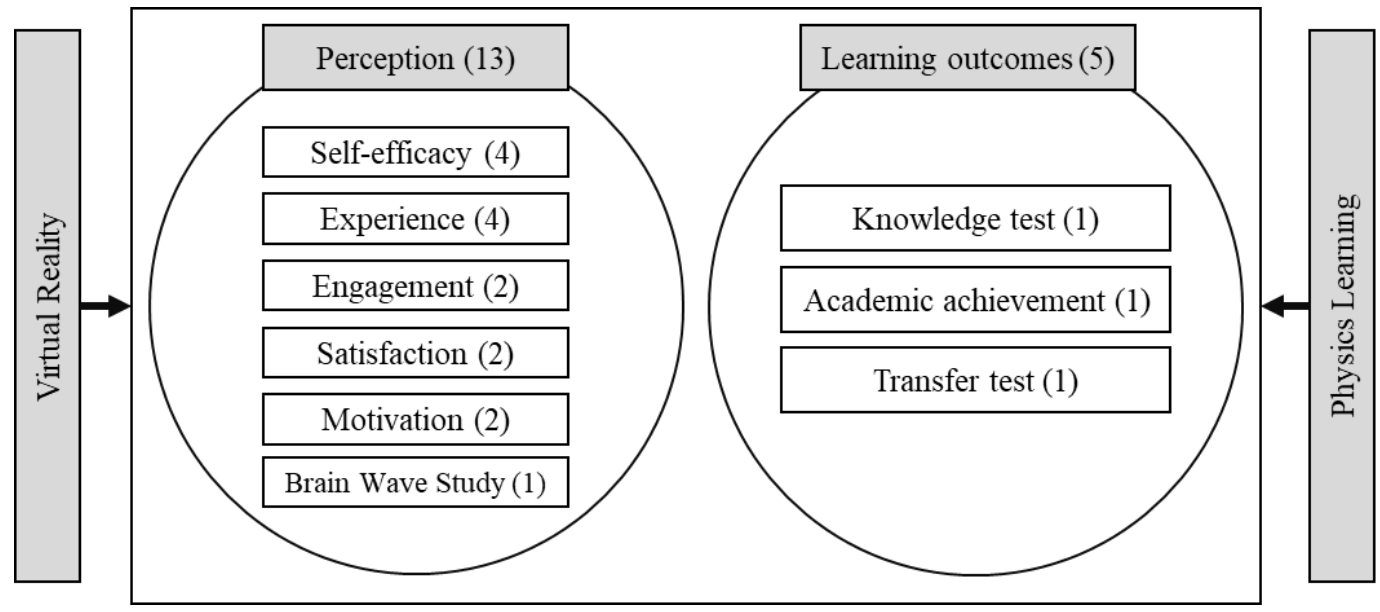

FIGURE 2. The framework between physics learning and virtual reality.

For example, the learning framework in Makransky, Terkildsen et al. (2019) investigated whether a higher level of immersion in the VR learning simulations leads to higher levels of student learning, self-report ratings, and brain-based measures of overload. The learning framework from this research is to measure "Learning outcome" using knowledge test and transfer test before and after experimenting (we code as "Pre-post Learning Outcome"). The research also measures student perception (i.e., level of presence, learning beliefs (self-efficacy), and satisfaction) after the experiment (we code as "post-perception"). After that, we also find VR tools used in the research, which is the Samsung Gear VR head-mounted display version (HMD), and we code it as "VR Headset".

\section{RESULTS AND DISCUSSION}

\section{Overall Finding}

By content analysis, it was found that the 15 papers reviewed discussed topics of learning related to virtual reality such as perception, self-efficacy, satisfaction, motivation, engagement, experience, and brain wave activity, learning outcomes, academic achievement, and intuitive understanding.

Among these topics, see the student perception (13) received the most common learning framework when using virtual reality in physics learning, such as self-efficacy (4), experience (4), satisfaction (2), motivation (2), engagement (2), and brain wave activity (1). For student perception, self-efficacy and experience received the most attention studies. Another term in the learning framework is learning outcomes (5), such as academic achievement (1), knowledge test (1), and a transfer test (1). For the learning outcome, many studies state learning outcome due to increased score in a specific concept, another way another study only mentions the particular aspect that teachers expect, such as academic achievement. The initial analysis suggested that when the virtual reality technology was applied to studies related to learning, the focus of discussion was mainly on the acquisition of student perception of self-efficacy and student experience (Tsivitanidou et al. 2021). Moreover, studying the impact of using VR through learning outcomes can also be another consideration (See FIGURE 2). 
We also analyze that the study also can evaluate learning outcomes in the study (Porter et al. 2020), student perception (Chamilothori et al. 2019; Arias et al. 2019; Pirker et al. 2018; Abichandani et al. 2019; O'Connor et al. 2018; Greenwald et al. 2018; Makransky et al. 2020; Kersting et al. 2020; Šiđanin et al. 2020), Brain wave activity (Lamb et al. 2018), and also can use both learning outcome and student perception (Makransky et al. 2019; Makransky et al. 2019; Chang et al. 2020; Liu et al. 2020).

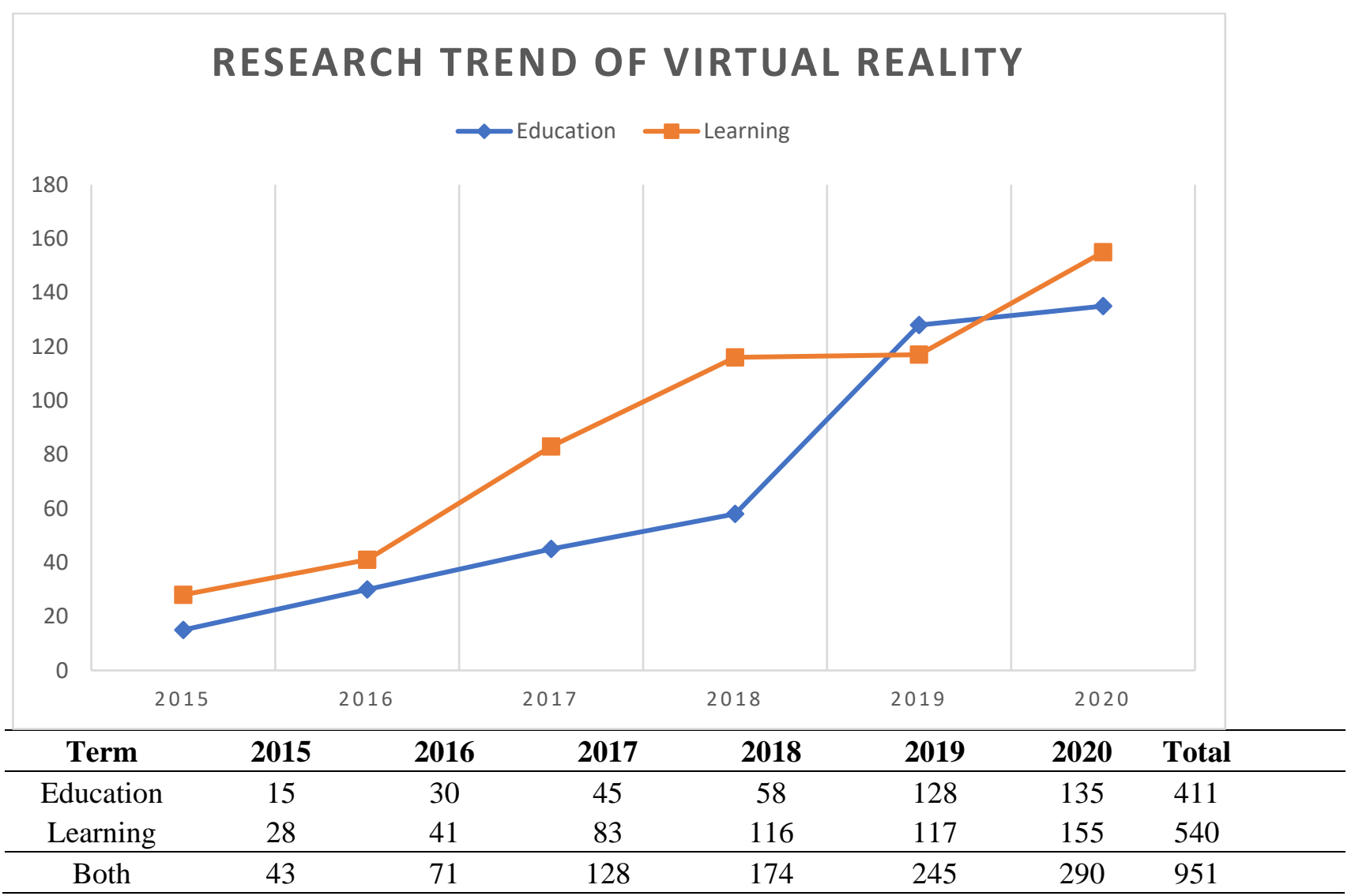

FIGURE 3. Trend in Virtual reality in Education.

Furthermore, we also analyze the trend of virtual reality usage in a broader theme of education and learning using the article record from different keywords after duplicate removed (951 studies). As FIGURE 3 shows, the number of virtual technology studies related to learning and education has increased significantly since 2015. This finding also similar to Shao-Chen Chang et al. (2020), which mention that virtual reality (VR) has become an important topic of education technology in recent years figures and tables.

\section{The Possibility of Virtual Reality}

The potential of virtual reality is enormous in the teaching activities of physics. For example, Arias et al. (2019) built a VR simulation for the facility that has not been built yet, the Future Circular Collider at CERN (European Organization for Nuclear Research). Its research has been a powerful tool for comparing evacuation installation effectiveness and investigating emergency scenarios in a unique facility. Another possibility of VR development could bring atomistic physics from microscale into user vision using VR simulation (O'Connor et al. 2018). The potential of VR can teachers bring to the classroom and make it an effective way to learn physics.

Furthermore, our review also mentions that interactive laboratory activity (5 studies) is the most potent activity that builds using VR. As mentioned by Georgiou et al. (2007), VR is also widely recognized as a significant technological advance that can facilitate the learning process by developing 
highly realistic 3D simulations supporting immersive and interactive features. After interactive laboratory activity, the most common study follows microscale concepts (4 studies) and Astrophysics ( 2 studies). The results suggest that the interactive laboratory activity will be the primary concern of VR simulation in physics for future study. This possibility of providing a proper laboratory also needs to be considered a researcher concern because not every school has a suitable laboratory to experiment. Therefore, VR application constitutes a cost-effective solution for schools and universities without appropriate infrastructure (Georgiou et al. 2007).

\section{Performance Measurement When Using Virtual Reality}

The performance measurement of virtual reality study will be analyzed based on Kirkpatrick's Model with a four-level evaluation model in instructional design (see Dick \& Johnson 2002; Kirkpatrick 1996). Kirkpatrick, in 1996 divide the evaluation process into four-level, namely Reaction, Learning, Behaviour, and Results (Dick and Johnson 2002).

Based on the review of an article, we get the result that post-perception (8 studies) is the most common evaluation process (i.e., level of presence, learning beliefs, satisfaction, learning motivation, self-efficacy, problem-solving tendency, metacognitive tendency, and cognitive load, engagement, immersion, learning experience, VR user experience, usability, intuitive Understanding, and technology acceptance). We define post-perception as the evaluation process that researchers do after experimenting. Based on Kirkpatrick, this evaluation uses the first level of the evaluation process (reaction) that sees the reaction or attitudes toward the learning experience, and questionnaires are the most used instrument to get an honest response from the learner (Dick and Johnson 2002).

Furthermore, student perception before and after the experiment (we code as "pre-post perception") was also shared in research (4 studies) (i.e., intrinsic motivation, self-efficacy, interest, and science aspirations). We confuse whether this "pre-post perception" approach is level 1 or level 2 in Kirkpatrick. Then, we categorize it as level 1 of Kirkpatrick because the aim of "pre-post perception" research is to see student reaction, even though using perception before and after.

For level 2 of evaluation by Kirkpatrick, a pre-test/post-test design was suggested to use the statistical technique of the day to demonstrate that learning has occurred as a result of the instruction (Dick and Johnson 2002). In this term, we categorize the "Learning outcomes using Pretest-posttest Experiment (4 studies) and "Pre-post Learning Outcome" between two groups (control and experiment) (3 studies) as level 2 in Kirkpatrick. Dick and Carey, in 1996 also mention that Kirkpatrick's level 1 and 2 assessment are the same as the questionnaire and post-test approach that instructional designers have used for several decades with the various article of their instruction (Dick and Johnson 2002).

The last approach that interesting in conduct the instructional design of VR is using brain wave activity using infrared spectroscopy (fNIRS) (1 study) (see Lamb et al. 2018). This research uses infrared spectroscopy to see the cognitive processing inside the brain when using video lectures, virtual reality (VR), Serious Educational Games (SEGs), and hands-on activities. The result suggests that SEGs and VR promote meaningful use of technology in the science classroom, providing disciplinary convergence through underlying cognitive attributes, affective factors, and skills implementation (Lamb et al. 2018). For further research, the instructional designer needs to consider this approach as the performance measurement to see the effects of instructional design on student learning using a persuasive approach (Brain Study).

\section{Popular Tools for Virtual Reality}

In VR development, the device (hardware) is an essential part because the interactiveness of a simulation also depends on the device type. We divide the kind of equipment into three types:

1. Watched VR, such as Google Cardboard and Samsung Cardboard.

2. Semi-interactive VR, in this type, Samsung with one controller, is the popular device.

3. Interactive VR has two versions, i.e., Desktop VR (e.g., HTC and Oculus), and Standalone VR (e.g., HTC and Oculus).

Firstly, watched VR. To use this device we need to use smartphone with the Gyroscope as the screen and we can see the VR screen. This VR device (e.g., the Samsung Gear VR or the Google Cardboard) 
provides cost-effective, dynamic, and mobile learning experiences and can be easily set up for in-class learning experiences (Pirker et al. 2018). In this review, four studies use the Watched VR as the tools to deliver physics concepts.

Secondly, semi-interactive VR, this device also uses a smartphone with the Gyroscope as the screen, but also can use our hand and interact with the virtual environment (e.g., Combination between Samsung Galaxy S6, and stereoscopically displayed through a Samsung Gear VR head-mounted display (HMD). In this review, two studies use this device to deliver the physics concept (Makransky, Mayer, et al. 2019; Makransky et al. 2020).

Thirdly, Interactive VR is the most popular device used in virtual reality study in physics (11 studies). For interactive VR, this device already has the factory's screen, and the user can directly use the device. However, in these developing, there are two kinds of devices, the desktop version that must plug into the computer to set the simulation and the standalone version that can set the simulation directly in the device. Moreover, because it is challenging to distinguish between the standalone version and desktop version, we consider all head-mounted display HMD that does not mention standalone. We would categorize it into the desktop version. In Interactive VR, HTC Vive (Taiwan Product) is the most powerful device to conduct the VR study (5 studies), and Oculus Rift (United State of America Product) is the second standard device (1 study).

Pirker compares what students like between these two devices (Watched VR and Interactive VR). However, many users feel more immersed and engaged by interactive room-scale setups (using Interactive VR). Additionally, the controllers that Interactive VR has to give users more possibilities to interact with experiments. This often creates more interesting hands-on experiences. Such virtual reality setups could be used in addition to classroom scenarios, such as part of provided self-directed learning labs (Pirker et al. 2018).

\section{CONCLUSION}

As our study results show, in these virtual reality studies, the theme of student perception, especially in self-efficacy and experience, has received the most attention, followed by satisfaction, motivation, and engagement. Meanwhile, the number of research aiming to examine the use of virtual reality has grown significantly in recent years. Moreover, student perception after the experiment is the most common evaluation process in conducting VR study in evaluation term. For the tool device, HTC Vive is the most powerful device to perform the VR study.

\section{REFERENCES}

Abichandani, P, McIntyre, W, Fligor, W, \& Lobo, D. 2019, 'Solar Energy Education through a CloudBased Desktop Virtual Reality System', IEEE Access, vol. 7, pp. 147081-147093.

Anita, A, \& Novianty, F. 2020 'The Students' Characters Analysis in Physics Learning Process', Jurnal Penelitian \& Pengembangan Pendidikan Fisika, vol. 6, no. 1, pp. 75-80.

Arias, S, La Mendola, S, Wahlqvist, J, Rios, O, Nilsson, D, \& Ronchi, E. 2019, 'Virtual Reality Evacuation Experiments on Way-Finding Systems for the Future Circular Collider', Fire Technology, vol. 55, no. 6, pp. 2319-2340.

Borrego, M, Foster, MJ, \& Froyd, JE. 2014, 'Systematic Literature Reviews in Engineering Education and Other Developing Interdisciplinary Fields', Journal of Engineering Education, John Wiley \& Sons, Ltd, vol. 103, no. 1, pp. 45-76.

Chamilothori, K, Wienold, J, \& Andersen, M. 2019, 'Adequacy of Immersive Virtual Reality for the Perception of Daylit Spaces: Comparison of Real and Virtual Environments', LEUKOS - Journal of Illuminating Engineering Society of North America, vol. 15, no. 2-3, pp. 203-226.

Chang, SC, Hsu, TC, Chen, YN, \& Jong, MS yung. 2020, 'The effects of spherical video-based virtual reality implementation on students' natural science learning effectiveness', Interactive Learning Environments, vol. 28, no. 7, pp. 915-929. 
Dick, W \& Johnson, RB. 2002, 'Evaluation in instructional design: The impact of Kirkpatrick's fourlevel model', Trends and Issues in Instructional Design and Technology, pp. 145-153.

Georgiou, J, Dimitropoulos, K, \& Manitsaris, A. 2007, 'A virtual reality laboratory for distance education in chemistry', International Journal of Social Sciences, vol. 2, no. 1, pp. 34-41.

Greenwald, SW, Corning, W, Funk, M, \& Maes, P. 2018, 'Comparing learning in virtual reality with learning on a 2D screen using electrostatics activities', Journal of Universal Computer Science, vol. 24 , no. 2 , pp. 220-245.

Hamilton, D, McKechnie, J, Edgerton, E, \& Wilson C. 2021 'Immersive virtual reality as a pedagogical tool in education: a systematic literature review of quantitative learning outcomes and experimental design', J. Comput. Educ, vol. 8, pp. 1-32.

Harzing, AW. 2007, Publish or Perish, available at: https://harzing.com/resources/publish-or-perish.

Kersting, M, Steier, R, \& Venville, G. 2021, 'Exploring participant engagement during an astrophysics virtual reality experience at a science festival', International Journal of Science Education, vol. 11, pp. 17-34.

Kirkpatrick, D. 1996, 'Great ideas revisited', Training \& Development, vol. 50, no. 1, pp. 54-60.

Lamb, R, Antonenko, P, Etopio, E, \& Seccia, A. 2018, 'Comparison of virtual reality and hands on activities in science education via functional near infrared spectroscopy', Computers and Education, vol. 124, pp. 14-26.

Liu, R, Wang, L, Lei, J, Wang, Q, \& Ren, Y. 2020, 'Effects of an immersive virtual reality-based classroom on students' learning performance in science lessons', British Journal of Educational Technology, vol. 51, no. 6, pp. 2034-2049.

Makransky, G, Mayer, RE, Veitch, N, Hood, M, Christensen, KB, \& Gadegaard, H. 2019, 'Equivalence of using a desktop virtual reality science simulation at home and in class', PLOS ONE, vol. 14, no. 4, pp. 1-14.

Makransky, G, Petersen, GB, \& Klingenberg, S. 2020, 'Can an immersive virtual reality simulation increase students' interest and career aspirations in science?', British Journal of Educational Technology, vol. 51, no. 6, pp. 2079-2097.

Makransky, G, Terkildsen, TS, \& Mayer, RE. 2019, 'Adding immersive virtual reality to a science lab simulation causes more presence but less learning', Learning and Instruction, vol. 60, pp. 225-236.

O'Connor, M, Deeks, HM, Dawn, E, Metatla, O, Roudaut, A, Sutton, M, Glowacki, BR, et al. 2018, 'Sampling molecular conformations and dynamics in a multi-user virtual reality framework', Science Adcanves, vol. 4, no. 6, pp. 1-9.

Pirker, J, Lesjak, I, Parger, M, \& Gütl, C. 2018, 'An educational physics laboratory in mobile versus room scale virtual reality - A comparative study', Lecture Notes in Networks and Systems, vol. 22, pp. 1029-1043.

Porter, CD, Smith, JRH, Stagar, EM, Simmons, A, Nieberding, M, Orban, CM, Brown, J, et al. 2020, 'Using virtual reality in electrostatics instruction: The impact of training', Physical Review Physics Education Research, vol. 16, no. 2, pp. 020119.1-020119.9.

Šiđanin, P, Plavšić, J, Arsenić, I, \& Krmar, M. 2020, 'Virtual reality (VR) simulation of a nuclear physics laboratory exercise', European Journal of Physics, vol. 41, no. 6, pp. 065802.1-065802.12.

Tsivitanidou, OE, Georgiou, Y, \& Ioannou, A. 2021 'A Learning Experience in Inquiry-Based Physics with Immersive Virtual Reality: Student Perceptions and an Interaction Effect Between Conceptual Gains and Attitudinal Profiles', J Sci Educ Technol, 25 June 2021. 
APPENDIX. Analysis of connection to learning in each reviewed study

\begin{tabular}{|c|c|c|c|c|c|c|}
\hline ID & Author & $\begin{array}{l}\text { Research } \\
\text { questions/purposes }\end{array}$ & $\begin{array}{l}\text { Related } \\
\text { learning } \\
\text { topic }\end{array}$ & $\begin{array}{l}\text { Virtual Reality } \\
\text { Headset }\end{array}$ & $\begin{array}{l}\text { Performance } \\
\text { Measurement }\end{array}$ & Concept \\
\hline 1 & $\begin{array}{l}\text { (Porter et al. } \\
2020)\end{array}$ & $\begin{array}{l}\text { To learn electrostatics } \\
\text { from subsequent VR } \\
\text { instruction }\end{array}$ & $\begin{array}{l}\text { Learning } \\
\text { outcomes }\end{array}$ & $\begin{array}{l}\text { Plastic Goggles or } \\
\text { Google Cardboard }\end{array}$ & $\begin{array}{l}\text { Learning } \\
\text { outcomes } \\
\text { using Pretest- } \\
\text { posttest } \\
\text { Experiment; } \\
\text { Post- } \\
\text { Perception }\end{array}$ & $\begin{array}{l}\text { Electrostatic } \\
\mathrm{s} \\
\text { distribution } \\
\text { of charge, } \\
\text { and the } \\
\text { vector field. }\end{array}$ \\
\hline 2 & $\begin{array}{l}\text { (Chamilothori } \\
\text { et al. 2019) }\end{array}$ & $\begin{array}{l}\text { To provide an } \\
\text { alternative environment } \\
\text { for the conduction of } \\
\text { subjective assessments } \\
\text { of daylit spaces }\end{array}$ & $\begin{array}{l}\text { Perception; } \\
\text { Satisfaction }\end{array}$ & $\begin{array}{l}\text { Oculus Rift } \\
\text { Development Kit } \\
2 \text { (DK2) }\end{array}$ & $\begin{array}{l}\text { Pre-Post } \\
\text { Perception } \\
\text { using } \\
\text { Experiment }\end{array}$ & $\begin{array}{l}\text { Five aspects } \\
\text { of subjective } \\
\text { perception } \\
\text { of daylit } \\
\text { spaces with } \\
\text { view in the } \\
\text { light (i.e., } \\
\text { pleasantness } \\
\text {, interest, } \\
\text { excitement, } \\
\text { complexity, } \\
\text { and } \\
\text { satisfaction). }\end{array}$ \\
\hline 3 & $\begin{array}{l}\text { (Makransky, } \\
\text { Terkildsen, et } \\
\text { al. 2019) }\end{array}$ & $\begin{array}{l}\text { To determine the } \\
\text { consequences of adding } \\
\text { immersive VR to } \\
\text { virtual learning } \\
\text { simulations, and to } \\
\text { investigate whether the } \\
\text { principles of } \\
\text { multimedia learning } \\
\text { generalize to } \\
\text { immersive VR. } \\
\text { To investigate whether } \\
\text { a higher level of } \\
\text { immersion in the VR } \\
\text { learning simulations } \\
\text { leads to higher levels of } \\
\text { student learning, self- } \\
\text { report ratings, and } \\
\text { brain-based measures } \\
\text { of overload. }\end{array}$ & $\begin{array}{l}\text { Learning } \\
\text { outcome; } \\
\text { level of } \\
\text { presence; } \\
\text { learning } \\
\text { beliefs (self- } \\
\text { efficacy); } \\
\text { Satisfaction. }\end{array}$ & $\begin{array}{l}\text { Samsung Galaxy } \\
\text { S6 phone, and } \\
\text { stereoscopically } \\
\text { displayed through } \\
\text { a Samsung } \\
\text { GearVR head- } \\
\text { mounted display } \\
\text { (HMD) }\end{array}$ & $\begin{array}{l}\text { Learning } \\
\text { outcomes (i.e., } \\
\text { a knowledge } \\
\text { test and a } \\
\text { transfer test) } \\
\text { using Pretest- } \\
\text { Posttest } \\
\text { Experiment; } \\
\text { Post- } \\
\text { Perception } \\
\text { (i.e., level of } \\
\text { presence, } \\
\text { learning } \\
\text { beliefs, and } \\
\text { satisfaction) }\end{array}$ & $\begin{array}{l}\text { Interactive } \\
\text { Laboratory } \\
\text { Activity }\end{array}$ \\
\hline
\end{tabular}




\begin{tabular}{|c|c|c|c|c|c|c|}
\hline ID & Author & $\begin{array}{l}\text { Research } \\
\text { questions/purposes }\end{array}$ & $\begin{array}{l}\text { Related } \\
\text { learning } \\
\text { topic }\end{array}$ & $\begin{array}{l}\text { Virtual Reality } \\
\text { Headset }\end{array}$ & $\begin{array}{l}\text { Performance } \\
\text { Measurement }\end{array}$ & Concept \\
\hline 4 & $\begin{array}{l}\text { (Makransky, } \\
\text { Mayer, et al. } \\
\text { 2019) }\end{array}$ & $\begin{array}{l}\text { To explore whether the } \\
\text { learning and } \\
\text { motivational outcomes } \\
\text { of interacting with a } \\
\text { desktop virtual reality } \\
\text { (VR) science lab } \\
\text { simulation on the } \\
\text { internet at home are } \\
\text { equivalent to } \\
\text { interacting with the } \\
\text { same simulation in } \\
\text { class with teacher } \\
\text { supervision. }\end{array}$ & $\begin{array}{l}\text { Learning } \\
\text { outcomes; } \\
\text { Perception; } \\
\text { Intrinsic } \\
\text { Motivation; } \\
\text { Self-efficacy }\end{array}$ & $\begin{array}{l}\text { Desktop Virtual } \\
\text { Reality (VR) (like } \\
\text { Oculus, HTC } \\
\text { Vive) }\end{array}$ & $\begin{array}{l}\text { Learning } \\
\text { outcomes from } \\
\text { two group } \\
\text { using Pretest- } \\
\text { Posttest } \\
\text { Experiment; } \\
\text { Pre-post } \\
\text { perception } \\
\text { (i.e., Intrinsic } \\
\text { Motivation } \\
\text { and Self- } \\
\text { Efficacy) }\end{array}$ & $\begin{array}{l}\text { Interactive } \\
\text { Laboratory } \\
\text { Activity }\end{array}$ \\
\hline 5 & $\begin{array}{l}\text { (Arias et al. } \\
2019 \text { ) }\end{array}$ & $\begin{array}{l}\text { To perform a } \\
\text { comparison of different } \\
\text { evacuation design } \\
\text { solutions, a set of } \\
\text { Virtual Reality (VR) } \\
\text { experiments involving } \\
\text { because the Future } \\
\text { Circular Collider } \\
\text { (FCC) facility is not } \\
\text { built yet. }\end{array}$ & Perception & $\begin{array}{l}\text { Head Mounted } \\
\text { Display } \\
\text { Technology } \\
\text { (HMD) using } \\
\text { HTC Vive }\end{array}$ & $\begin{array}{l}\text { Post- } \\
\text { Perception } \\
\text { after } \\
\text { Experiment }\end{array}$ & $\begin{array}{l}\text { Actual } \\
\text { tunnel } \\
\text { accelerator } \\
\text { configuratio } \\
\mathrm{n} \text { of the } \\
\text { Large } \\
\text { Hadron } \\
\text { Collider at } \\
\text { CERN.6 }\end{array}$ \\
\hline 6 & $\begin{array}{l}\text { (Chang et al. } \\
\text { 2020) }\end{array}$ & $\begin{array}{l}\text { To introduce a VR } \\
\text { guidance system design } \\
\text { activity and a } \\
\text { conventional VR } \\
\text { guidance activity to } \\
\text { help students learn the } \\
\text { knowledge of coastal } \\
\text { erosion in a natural } \\
\text { science course. }\end{array}$ & $\begin{array}{l}\begin{array}{l}\text { Learning } \\
\text { outcomes; }\end{array} \\
\text { Perception; } \\
\text { Learning } \\
\text { motivation; } \\
\text { Self-efficacy; } \\
\text { Problem- } \\
\text { solving } \\
\text { tendency; } \\
\text { Metacognitiv } \\
\text { e tendency; } \\
\text { Cognitive } \\
\text { Load. }\end{array}$ & $\begin{array}{l}\text { Plastic Goggles or } \\
\text { Google Cardboard }\end{array}$ & $\begin{array}{l}\text { Learning } \\
\text { outcomes from } \\
\text { two group } \\
\text { using Pretest- } \\
\text { Posttest } \\
\text { Experiment; } \\
\text { Post- } \\
\text { Perception } \\
\text { (i.e., learning } \\
\text { motivation, } \\
\text { self-efffcacy, } \\
\text { problem- } \\
\text { solving } \\
\text { tendency, } \\
\text { metacognitive } \\
\text { tendency, and } \\
\text { cognitive } \\
\text { load). }\end{array}$ & $\begin{array}{l}\text { Coastal } \\
\text { Erosion; } \\
\text { Collision }\end{array}$ \\
\hline 7 & $\begin{array}{l}\text { (Pirker et al. } \\
\text { 2018) }\end{array}$ & $\begin{array}{l}\text { To compare } \\
\text { experiences with a } \\
\text { cost-effective mobile } \\
\text { setup with a mobile VR } \\
\text { experience through } \\
\text { Samsung GEAR and } \\
\text { compare it with a more } \\
\text { interactive VR } \\
\text { experience in room- } \\
\text { scale VR with HTC } \\
\text { Vive. }\end{array}$ & $\begin{array}{l}\text { Engagement; } \\
\text { Immersion; } \\
\text { Learning } \\
\text { experience; } \\
\text { Usability }\end{array}$ & $\begin{array}{l}\text { Samsung Gear VR } \\
\text { (Google } \\
\text { Cardboard } \\
\text { Version) and } \\
\text { Samsung Galaxy } \\
\text { S6 } \\
\text { vs. } \\
\text { HTC Vive, using } \\
\text { two controllers }\end{array}$ & $\begin{array}{l}\text { Post- } \\
\text { Perception } \\
\text { after using two } \\
\text { different } \\
\text { setups (i.e., } \\
\text { engagement, } \\
\text { immersion, } \\
\text { learning } \\
\text { experience, } \\
\text { VR user } \\
\text { experience, } \\
\text { and usability). }\end{array}$ & $\begin{array}{l}\text { General } \\
\text { Physics }\end{array}$ \\
\hline 8 & $\begin{array}{l}\text { (Abichandani } \\
\text { et al. 2019) }\end{array}$ & $\begin{array}{l}\text { To provides an } \\
\text { innovative approach to } \\
\text { solar energy and } \\
\text { electrical engineering }\end{array}$ & Perception & $\begin{array}{l}\text { Desktop Virtual } \\
\text { Reality (e.g., }\end{array}$ & $\begin{array}{l}\text { Pre and Post } \\
\text { Perception }\end{array}$ & $\begin{array}{l}\text { Solar } \\
\text { Energy (i.e., }\end{array}$ \\
\hline
\end{tabular}




\begin{tabular}{|c|c|c|c|c|c|c|}
\hline ID & Author & $\begin{array}{l}\text { Research } \\
\text { questions/purposes }\end{array}$ & $\begin{array}{l}\text { Related } \\
\text { learning } \\
\text { topic }\end{array}$ & $\begin{array}{l}\text { Virtual Reality } \\
\text { Headset }\end{array}$ & $\begin{array}{l}\text { Performance } \\
\text { Measurement }\end{array}$ & Concept \\
\hline & & $\begin{array}{l}\text { education by } \\
\text { alleviating the need for } \\
\text { a substantial } \\
\text { investment in terms of } \\
\text { equipment, facilities, } \\
\text { laboratory space, field } \\
\text { trips, and personnel. }\end{array}$ & & $\begin{array}{l}\text { Oculus, HTC } \\
\text { Vive) }\end{array}$ & $\begin{array}{l}\text { using } \\
\text { Experiment }\end{array}$ & $\begin{array}{l}\text { Photovoltaic } \\
\text { (PV) cells, } \\
\text { solar (PV) } \\
\text { modules, } \\
\text { and solar } \\
\text { (PV) array } \\
\text { installation } \\
\text { conffguratio } \\
\text { ns). }\end{array}$ \\
\hline 9 & $\begin{array}{l}\text { (O'Connor et } \\
\text { al. 2018) }\end{array}$ & $\begin{array}{l}\text { To develop a real-time } \\
\text { molecular simulation } \\
\text { and manipulation } \\
\text { framework such a } \\
\text { fascinating challenge, } \\
\text { which must necessarily } \\
\text { consider aesthetics, } \\
\text { design, and user } \\
\text { psychology to be } \\
\text { effective. }\end{array}$ & $\begin{array}{l}\text { Perception; } \\
\text { Familiarity; } \\
\text { Experience }\end{array}$ & HTC Vive VR & $\begin{array}{l}\text { Post- } \\
\text { Perception } \\
\text { (i.e., } \\
\text { familiarity or } \\
\text { experienced) }\end{array}$ & $\begin{array}{l}\text { Atomistic } \\
\text { physics } \\
\text { simulations }\end{array}$ \\
\hline 10 & $\begin{array}{l}\text { (Greenwald et } \\
\text { al. 2018) }\end{array}$ & $\begin{array}{l}\text { To investigate the } \\
\text { differences between } \\
\text { VR and 2D learning } \\
\text { environments. }\end{array}$ & $\begin{array}{l}\text { Perception; } \\
\text { Intuitive } \\
\text { understandin } \\
\mathrm{g} ;\end{array}$ & Not Define & $\begin{array}{l}\text { Post- } \\
\text { Perception } \\
\text { (i.e., Intuitive } \\
\text { Understanding } \\
\text { ) between two } \\
\text { devices }\end{array}$ & $\begin{array}{l}\text { Electricity } \\
\text { and } \\
\text { Magnetism. }\end{array}$ \\
\hline
\end{tabular}

\begin{tabular}{|c|c|c|c|c|c|c|}
\hline 11 & $\begin{array}{l}\text { (Makransky } \\
\text { et al. 2020) }\end{array}$ & $\begin{array}{l}\text { To investigate the } \\
\text { value of using } \\
\text { Immersive Virtual } \\
\text { Reality (IVR) } \\
\text { laboratory simulations } \\
\text { in science education. }\end{array}$ & $\begin{array}{l}\text { Interest; } \\
\text { Self-efficacy; } \\
\text { Science } \\
\text { aspiration }\end{array}$ & $\begin{array}{l}\text { Samsung Galaxy } \\
\text { S7 or S8 phones, } \\
\text { and } \\
\text { stereoscopically } \\
\text { displayed through } \\
\text { a Samsung Gear } \\
\text { VR }\end{array}$ & $\begin{array}{l}\text { Pre and Post } \\
\text { Perception } \\
\text { (i.e., interest, } \\
\text { self-efficacy, } \\
\text { and science } \\
\text { aspirations) }\end{array}$ & $\begin{array}{l}\text { The } \\
\text { simulation } \\
\text { on the topic } \\
\text { of } \\
\text { Microstructu } \\
\text { re analysis; } \\
\text { Laboratory } \\
\text { safety } \\
\text { simulation }\end{array}$ \\
\hline 12 & $\begin{array}{l}\text { (Liu et al. } \\
\text { 2020) }\end{array}$ & $\begin{array}{l}\text { To make students } \\
\text { obtain better academic } \\
\text { achievement and show } \\
\text { stronger engagement } \\
\text { with the science } \\
\text { lessons in an IVR- } \\
\text { based classroom than } \\
\text { in a classroom in which } \\
\text { traditional teaching } \\
\text { methods are used. }\end{array}$ & $\begin{array}{l}\begin{array}{l}\text { Learning } \\
\text { outcome; }\end{array} \\
\text { Academic } \\
\text { achievement; } \\
\text { Post- } \\
\text { perception; } \\
\text { Engagement } \\
\text { Technology } \\
\text { acceptance }\end{array}$ & $\begin{array}{l}\text { Immersive virtual } \\
\text { reality or Head- } \\
\text { Mounted Displays } \\
\text { (HMD) (e.g., } \\
\text { Oculus, HTC } \\
\text { Vive) }\end{array}$ & $\begin{array}{l}\text { Pre-post } \\
\text { Learning } \\
\text { Outcome (i.e., } \\
\text { academic } \\
\text { achievement) } \\
\text { between two } \\
\text { group; } \\
\text { Post- } \\
\text { perception } \\
\text { (i.e., } \\
\text { engagement } \\
\text { and } \\
\text { technology } \\
\text { acceptance) }\end{array}$ & $\begin{array}{l}\text { General } \\
\text { Physics }\end{array}$ \\
\hline 13 & $\begin{array}{l}\text { (Kersting et } \\
\text { al. 2021) }\end{array}$ & $\begin{array}{l}\text { To investigate, } \\
\text { compare, and } \\
\text { characterize interactive } \\
\text { VR-based preservice } \\
\text { science teacher clinical } \\
\text { teaching environments }\end{array}$ & Perception & $\begin{array}{l}\text { VR Glasses or } \\
\text { Google Cardboard }\end{array}$ & $\begin{array}{l}\text { Post- } \\
\text { Perception } \\
\text { (using Video } \\
\text { Recoding, VR } \\
\text { Screen } \\
\text { Capture, and }\end{array}$ & $\begin{array}{l}\text { Astrophysic } \\
\mathrm{s} ; \\
\text { Virtual } \\
\text { Universe in } \\
\text { Astronomica }\end{array}$ \\
\hline
\end{tabular}




\begin{tabular}{|c|c|c|c|c|c|c|}
\hline ID & Author & $\begin{array}{l}\text { Research } \\
\text { questions/purposes }\end{array}$ & $\begin{array}{l}\text { Related } \\
\text { learning } \\
\text { topic }\end{array}$ & $\begin{array}{l}\text { Virtual Reality } \\
\text { Headset }\end{array}$ & $\begin{array}{l}\text { Performance } \\
\text { Measurement }\end{array}$ & Concept \\
\hline & & $\begin{array}{l}\text { with those of real-life } \\
\text { teaching environments. }\end{array}$ & & & $\begin{array}{l}\text { Focus Group } \\
\text { Interview) }\end{array}$ & $\begin{array}{l}\text { l } \\
\text { Phenomena. }\end{array}$ \\
\hline 14 & $\begin{array}{l}\text { (Lamb et al. } \\
2018)\end{array}$ & $\begin{array}{l}\text { To investigate } \\
\text { differences in the level } \\
\text { of hemodynamic } \\
\text { response as it relates to } \\
\text { four different } \\
\text { approaches to teaching } \\
\text { topics in the life } \\
\text { sciences. }\end{array}$ & $\begin{array}{l}\text { Brain wave } \\
\text { activity }\end{array}$ & HTC Vive & $\begin{array}{l}\text { Brain Wave } \\
\text { Activity using } \\
\text { infrared } \\
\text { spectroscopy } \\
\text { (fNIRS) }\end{array}$ & $\begin{array}{l}\text { Deoxyribon } \\
\text { ucleic acid } \\
\text { (DNA) } \\
\text { replication; } \\
\text { Microscopis } \\
\text { Analysis }\end{array}$ \\
\hline 15 & $\begin{array}{l}\text { (Šiđanin et al. } \\
\text { 2020) }\end{array}$ & $\begin{array}{l}\text { To design which } \\
\text { includes all the stages } \\
\text { of the physical } \\
\text { measurement process. } \\
\text { Following the VR } \\
\text { experiment, the } \\
\text { students receive pre- } \\
\text { prepared experimental } \\
\text { data (gamma spectra) } \\
\text { from which they } \\
\text { extract a specific result } \\
\text { (in this case, the mass } \\
\text { of the deuteron) and } \\
\text { accordingly validate } \\
\text { some of the knowledge } \\
\text { they acquire in the } \\
\text { classroom. }\end{array}$ & Experience & $\begin{array}{l}\text { Oculus Rift head- } \\
\text { mounted display } \\
\text { (HMD) }\end{array}$ & $\begin{array}{l}\text { Explain } \\
\text { Experience the } \\
\text { experimental } \\
\text { Setting }\end{array}$ & $\begin{array}{l}\text { Nuclear } \\
\text { Physics }\end{array}$ \\
\hline
\end{tabular}


